\title{
PERAN PERAWAT DALAM MENGANALISIS BUDAYA ORGANISASI DAN BUDAYA KESELAMATAN PASIEN DI RUMAH SAKIT
}

\author{
Muhaini Atmayana Purba / 181101131 \\ muhainipurba21@gmail.com
}

\begin{abstract}
ABSTRAK
Latar belakang : Membangun budaya keselamatan pasien merupakan langkah awal dalam pengembangan keselamatan pasien. Budaya keselamatan pasien di rumah sakit merupakan bagian dari budaya organisasi, sehingga pengkajian tentang budaya organisasi diperlukan untuk menjadi panduan dalam mengembangkan keselamatan pasien. Tujuan : Tujuan penulisan ini yaitu mengidenifikasi peran perawat dalam menganalisis budaya organisasi dan budaya keselamatan pasien di rumah sakit. Metode : Metode yang digunakan merupakan literatur review atau suatu perbandingan atau analisis antara satu jurnal dengan jurnal lainnya dari berbagai sumber seperti referensi jurnal, buku teks dan e-book. Hasil : Tipe budaya Clan didapatkan sebagai tipe budaya organisasi yang dominan sekaligus kuat dan menjadi panduan untuk melakukan perubahan dalam organisasi khususnya dalam pengembangan keselamatan pasien. Rencana tindak lanjut dibuat dan disepakati dalam Consensus Decision Making Group (CDMG) untuk mengartikulasikan unsur keselamatan pasien dalam visi dan misi organisasi serta penguatan budaya keselamatan melalui pelatihan keselamatan pasien bagi seluruh staf. Kesimpulan : . Rencana dalam tindak lanjut dibuat dan disepakati dalam Consensus Decision Making Group (CDMG) untuk mengartikulasikan unsur keselamatan pasien dalam visi dan misi organisasi serta penguatan budaya keselamatan melalui pelatihan keselamatan pasien bagi seluruh staf dan juga perawat.
\end{abstract}

Kata Kunci : Peran perawat, budaya organisasi, budaya keselamatan pasien, rumah sakit.

\begin{abstract}
Background : Building a culture of patient safety is the first step in developing patient safety. Patient safety culture in hospitals is part of the organizational culture, so an assessment of organizational culture is needed to be a guide in developing patient safety. Purpose : The purpose of this paper is to identify the role of nurses in analyzing organizational culture and patient safety culture in hospitals. Method : The method used is a literature review or a comparison or analysis of one journal with other journals from various sources such as journal references, textbooks and e-books. Results : Clan culture type was found as a dominant and strong type of organizational culture and became a guide for making changes in the organization, especially in the development of patient safety. A follow-up plan was made and agreed in the Consensus Decision Making Group (CDMG) to articulate the elements of patient safety in the vision and mission of the organization and strengthen safety culture through patient safety training for all staff. Conclusion : A follow-up plan is made and agreed on in the Consensus Decision Making Group (CDMG) to articulate the elements of patient safety in the organization's vision and mission and strengthen the safety culture through patient safety training for all staff and nurses.
\end{abstract}

Keywords : Role of nurses, organizational culture, patient safety culture, hospital. 


\section{Latar Belakang}

Keselamatan pasien merupakan inti dari mutu pelayanan kesehatan. Untuk mencapainya, diperlukan komitmen yang kuat dari individu maupun tim. Kombinasi dari berbagai elemen di rumah sakit, secara bersamasama menghasilkan sebuah situasi yang berisiko tinggi. Untuk dapat memahami risiko yang ada dalam sebuah proses yang kompleks pada pelayanan medis/ kesehatan, diperlukan informasi tentang berbagai kasus error dan nearmissed yang pernah dan dapat terjadi. Dari situ kita dapat belajar untuk menutup kesenjangan yang ada, mengurangi morbiditas dan mortalitas untuk mencapai mutu pelayanan yang diharapkan (WHO Patient Safety Curiculum, 2011).

Komitmen terhadap keselamatan pasien berkembang luas sejak akhir dekade 1990-an. Hal ini diinduksi oleh dua laporan yang sangat berpengaruh : To Err is Human, yang disampaikan oleh Institute Of Medicine (IOM) pada tahun 1999, dan An Organization with Memory dari UK Government's Chief Medical Officer pada tahun 2000. Kedua laporan tersebut menyatakan bahwa kesalahan terjadi secara rutin dalam menjalankan pelayanan kesehatan, dan meliputi $10 \%$ dari admisi di rumah sakit. Kesalahan yang terjadi sangat serius, bahkan fatal. Dua penelitian besar, satu dilakukan di Colorado dan Utah dan yang lainnya di New York, menemukan bahwa efek adverse event terjadi pada 2,9 dan 3,7 persen dari rawat inap. Di rumah sakitrumah sakit Colorado dan Utah, 6,6 persen dari adverse event menyebabkan kematian, sementara di rumah sakit di New York sebesar 13,6 persen. Dalam kedua studi ini, lebih dari setengah dari adverse event merupakan akibat kesalahan medis yang bisa dicegah (Kohn et al, 2001).

Sejak publikasi kedua laporan tersebut, upaya untuk meningkatkan keselamatan dalam pelayanan pasien menjadi sebuah gerakan global. Hal ini menyebabkan transformasi yang luar biasa dalam cara pandang terhadap patient safety. Walaupun demikian, kondisi keselamatan pasien saat ini di seluruh dunia masih memprihatinkan. Dengan pengumpulan data tentang penyebab error dan adverse event atau Kejadian Tak Diharapkan (KTD) yang semakin baik, maka semakin jelas pula bahwa pelayanan yang tidak aman merupakan gambaran yang nyata dari setiap aspek pelayanan kesehatan 
(Donaldson, dalam WHO Patient Safety

Curiculum, 2011).

Setiap organisasi memiliki budaya yang dapat memberi pengaruh bermakna terhadap sikap dan perilaku dari anggotanya. Kompetensi dan nilainilai dari staf dan pimpinan memegang peranan kunci yang menentukan efektifitas dan keberhasilan organisasi (Lunenburg, 2011). Demikian pula halnya dengan Perkumpulan Budi Kemuliaan. Sebagai sebuah organisasi nirlaba yang bergerak di bidang kesehatan reproduksi, yang pada tahun 2012 lalu telah mencapai usia 100 tahun, Budi Kemuliaan menghadapi tantangan yang besar dalam beradaptasi dengan tuntutan internal maupun eksternal organisasi. Para pemimpinnya harus dapat menjelaskan bagaimana bekerja secara efisien dan efektif dalam menghadapi tantangan tersebut. Visi Budi Kemuliaan menjelaskan keinginan para pendahulunya untuk menjadi pelopor dan inspirator dalam menciptakan generasi yang berkualitas. Visi ini dterjemahkan oleh para penerus yang memimpin organisasi dalam bentuknya yang aktual, yaitu berusaha untuk menjadi role model dalam upaya meningkatkan kesehatan perempuan dan generasi. Peluang untuk melakukan hal ini terbentang luas dengan adanya kesempatan bagi Budi Kemuliaan untuk terlibat dalam gerakan penyelamatan perempuan dan bayi baru lahir. Walaupun gerakan ini dipicu oleh kekuatan eksternal, namun Budi Kemuliaan memandang bahwa hal ini sangat sejalan dengan apa yang menjadi cita-cita luhur Budi Kemuliaan, dan sangat optimis bahwa gerakan ini akan mampu mengakselerasi pencapaian visi tersebut.

Secara internal, Budi Kemuliaan terus-menerus bekerja untuk menghasilkan pelayanan yang bermutu. Organisasi ini berusaha menegakkan Corporate dan Clinical Governance yang baik. Ronde manajemen, ronde klinik, laporan pagi, audit kasus, serta rapat-rapat rutin direksi maupun internal bidang/unit merupakan kegiatan yang sudah menjadi ritual organisasi. Dasar dari seluruh aktivitas ini adalah keinginan yang kuat untuk menjaga akuntabilitas organisasi dan meningkatkan mutu secara berkelanjutan. Akuntabilitas ini perlu dijaga karena tuntutan terhadap kiprah Budi Kemuliaan di lingkungan eksternal semakin meningkat.

Kesadaran untuk menjaga akuntabilitas ini semakin dirasakan di 
seluruh lapisan dalam organisasi ini. RSIA Budi Kemuliaan sangat menyadari bahwa tuntutan lingkungan eksternal yang mengingankan peran Budi Kemuliaan diperluas, harus diimbangi dengan stabilitas internal organisasi yang ditandai dengan terpeliharanya mutu dari produk/jasa yang dihasilkan. Keselamatan Pasien adalah inti dari mutu pelayanan di RSIA Budi Kemuliaan berbenah diri untuk dapat menjawab tantangan tersebut. Keberlangsungan organisasi ini tidak terlepas dari budaya dan nilai-nilai yang merupakan bagian yang paling fundamental dalam suatu organisasi.

RSIA Budi Kemuliaan yang mempunyai misi "Menjadi lembaga kesehatan yang diakui mampu menyediakan pelayanan kesehatan yang terbaik dan terjangkau oleh seluruh lapisan masyarakat", adalah rumah sakit tipe B Khusus yang menyediakan pelayanan kesehatan maternal, neonatal serta kesehatan anak. Upaya patient safety di Budi Kemuliaan sesungguhnya telah dimulai dengan adanya Manajemen Risiko jauh sebelum Tim Keselamatan Pasien Rumah Sakit (KPRS) dibentuk pada awal tahun 2012. Manajemen risiko sendiri merupakan bagian dari implementasi Clinical
Governance dan Corporate Governance yang dituangkan dalam Hospital By Laws RSIA Budi Kemuliaan. Dengan adanya Tim KPRS, kegiatan manajemen Risiko di integrasikan ke dalamnya dan disebut sebagai Tim KPRS-Manajemen Risiko.

\section{Tujuan}

Tujuan penulisan ini yaitu mengidenifikasi peran perawat dalam menganalisis budaya organisasi dan budaya keselamatan pasien di rumah sakit.

\section{Metode}

Metode yang digunakan merupakan literatur review atau suatu perbandingan atau analisis antara satu jurnal dengan jurnal lainnya dari berbagai sumber seperti referensi jurnal, buku teks dan e-book.

\section{Hasil \& Pembahasan}

Keselamatan pasien rumah sakit adalah suatu sistem dimana rumah sakit membuat asuhan pasien lebih aman yang meliputi asesmen risiko, identifikasi dan pengelolaan hal yang berhubungan dengan risiko pasien, pelaporan dan analisis insiden, kemampuan belajar dari insiden dan tindak lanjutnya serta implementasi solusi untuk meminimalkan timbulnya risiko dan mencegah terjadinya cedera yang disebabkan oleh kesalahan akibat 
melaksanakan suatu tindakan atau tidak mengambil tindakan yang seharusnya diambil (Peraturan Menteri Kesehatan RI Nomor 1691, 2011).

Menurut WHO, Keselamatan pasien adalah tidak adanya bahaya yang dapat dicegah pada pasien selama proses asuhan kesehatan. Disiplin keselamatan pasien adalah upaya terkoordinasi untuk mencegah kerusakan yang terjadi pada pasien, yang disebabkan oleh proses asuhan kesehatan itu sendiri (WHO Patient Safety). Sedangkan definisi keselamatan pasien menurut KKP-RS adalah bebasnya pasien dari harm/cedera yang tidak seharusnya terjadi atau bebas dari harm yang potensial akan terjadi (seperti penyakit, cedera fisik / sosial /psikologis, cacad, kematian, dan lainlain), terkait dengan pelayanan kesehatan (Pedoman Pelaporan Insidens Keselamatan Pasien).

\section{Budaya Keselamatan Pasien}

Menurut The Health Foudation, 2011, budaya keselamatan berkaitan dengan sejauh mana organisasi memprioritaskan dan mendukung peningkatan keselamatan dengan aman. Organisasi dengan budaya keselamatan positif memiliki komunikasi atas dasar saling percaya, persepsi bersama tentang pentingnya keselamatan, keyakinan pada efektivitas langkahlangkah pencegahan, dan dukungan bagi tenaga kerja.

\section{Budaya Organisasi}

Dalam bukunya Organizational Culture and Leadership, Edgar Schein mendefinisikan budaya sebagai satu set dasar asumsi yang mendefinisikan bagi kita apa yang kita perhatikan, apa arti dari berbagai hal, dan bagaimana bereaksi secara emosional terhadap apa yang sedang terjadi, dan tindakan apa yang harus diambil dalam berbagai macam situasi" . Definisi Schein menunjukkan bahwa pemimpin yang ingin menerapkan perubahan radikal dari "norma" dalam suatu organisasi perlu untuk mempengaruhi dan akhirnya mengubah budaya sebelum memimpin upaya perubahan organisasi yang sukses (Russell, 2001). Schein menjelaskan bahwa budaya organisasi dapat dianalisis dalam beberapa level yang berbeda, yaitu artefak, nilai-nilai dan keyakinan, serta asumsi dasar. Nilai dan norma berada pada level menengah dari model tingkatan budaya tersebut. Dua lapisan lainnya adalah lapisan paling superfiisal yaitu artefak, sedangkan lapisan yang terdalam adalah asumsi dasar. 
Penelitian ini diarahkan untuk menyusun rencana pengembangan budaya keselamatan pasien berdasarkan hasil analisis budaya organisasi dan budaya keselamatan pasien. Hal ini dilakukan melalui dua tahap, yaitu tahap pertama dilakukan survey budaya keselamatan pasien kepada 152 responden dari staf klinik dan secara bersamaan dilakukan pula survey budaya organisasi kepada 15 orang anggota direksi dan manajemen senior. Tahap ke dua adalah penyusunan rencana tindak lanjut (RTL) yang dilakukan dalam Consensus Decision Making Group (CDMG).

Berdasarkan teori-teori tersebut, maka pengukuran budaya keselamatan pasien akan mendapatkan gambaran dimensi-dimensi b budaya keselamatan yang menjadi kekuatan dan kelemahan. Tiap-tiap tipe budaya organisasi memiliki strategi mutu masing-masing. Profil budaya organisasi yang berhasil diidentifikasi akan menentukan strategi mutu yang akan digunakan dalam menetapkan langkah-langkah pengembangan keselamatan pasien.

\section{Penutup}

\section{Kesimpulan}

Berdasarkan hasil dan analisis dari penelitian ini, maka dapat diambil beberapa kesimpulan sebagai berikut:

1. Dimensi budaya keselamatan pasien yang terkuat adalah Kerjasama dalam unit, dan yang terlemah adalah Staffing dan respons non punitive.

2. Tipe budaya organisasi yang dominan di RSIA Budi Kemuliaan adalah budaya Clan. Selain dominan, budaya Clan juga merupakan budaya yang kuat dalam organisasi ini. Budaya Clan kondusif untuk keselamatan pasien namun dapat menjadi hambatan karena hubungan interpersonal yang kuat dapat memberikan ruang pemakluman yang besar yang dapat menghampat penegakkan disiplin dan standard.

\section{Saran}

1. Memasukkan unsur keselamatan pasien dalam pernyataan visi, misi dan nilai- nilai organisasi.

2. Menunjukkan komitmen dan dukungan nyata dalam implementasi program keselamatan pasien melalui Ronde Keselamatan Pasien yang dilakukan secara rutin.

3. Pimpinan melengkapi diri dengan safety leadership dan 
kompetensinya

sebelum

menerapkannya pada karyawan

dengan mengikuti pelatihan

Keselamatan Pasien Rumah Sakit.

4. Peran dan tanggung jawab staf dalam keselamatan pasien diartikulasikan secara jelas dalam penilaian kinerja dan jobdesciption dan diberikan umpan balik yang tepat dalam suatu sistem reward yang adekuat.

5. Sosialisasi tentang keselamatan pasien dilakukan kepada seluruh karyawan sejak proses rekrutmen atau seleksi dan dilakukan secara berkala setelah diterima sebagai karyawan.

6. Memastikan diseminasi informasi tentang insidens keselamatan pasien terutama yang terkait dengan rekomendasi dari pembelajaran insidens disampaikan kepada seluruh karyawan melalui para champion dan kepala ruangan/unit.

7. Mereview rencana strategis dan roadmap rumah sakit yang selama ini memang belum pernah dilakukan.

8. Perlunya penelitian lanjutan tentang pengukuran budaya keselamatan pasien untuk kelompok profesi yang berbeda, membandingkan budaya antar unit atau antar rumah sakit.

\section{Daftar Pustaka}

Agency for Healthcare Research and Quality, Rockville MD , 2012, Surveys on Patient Safety Culture. Sitasi dari www.ahrq.gov/professionals/quali ty-patientsafety/pati entsafetyculture/ index.html.

Cameron KS, Quinn RE, 2011, Diagnosing and Changing Organizational Culture Based on the Competing Values Framework - Third Edition.

Cahyono, Suharjo. (2008) Membangun Budaya Keselamatan Pasien dalam Praktik Kedokteran. Yogyakarta : Kanisius

Easton K, Margon T. 2009. Medication Errors in Outpatients of $A$ Government Hospital in Yogyakarta Indonesia. 1(1) : 8 10

Fatalina Femi, Sunartini, Widyandana, Sedyowinarso Mariyono. 2015. Persepsi dan penerimaan Interprofessional Collaborative Practice Bidang Maternitas pada tenaga kesehatan. Universitas Gadjah Mada : Fakultas 
Kedokteran. Jurnal Kedokteran Indonesia

Iskandar, Heru, Halimi Maksum, dan Nafisah. (2014). Faktor Penyebab Penurunan Pelaporan Insiden Keselamatan Pasien Rumah Sakit. Malang : Fakultas Kedokteran Universitas Brawijaya Malang, 2014 Nugroho, SriH.P., Sujianto,U. Supervisi Kepala Ruang Model Proctor Untuk Meningkatkan Pelaksanaan Keselamatan Pasien. Jurnal Keperawatan Indonesia.20, (1):56-64

Iyer Patricia W, \& Nancy H Camp. 2004. Dokumentasi Keperawatan. Jakarta: EGC.

Klehr, J, dkk. 2009. Menggambarkan dokemuntasi pada catatan sistem elektronik rekam medis yang memberikan catatan elektronik kesehatan.

Lestari, Yani., Saleh, Ariyanti., Pasinringi, Syahrir. 2017. Hubungan Interprofessional Kolaborasi dengan Pelaksanaan Catatan Perkembangan Pasien Terintegrasi di RSUD Prof Dr H.M Anwar Makkatutu Kabupaten Bantaeng. JST
Kesehatan, Januari 2017, Vol. 7 No. $1: 85-90$.

Morgan, S., Pullon, S., McKinlay, E., 2015. Observation of interprofessional collaborative practice in primary care teams: an integrative literature review. Int. J. Nurs. Stud. 52 (7), 12171230.

Morris F \& Boussebbass. 2010. Coordination of Physicians Operational Activities : A Contingency Perspective.

Notoatmodjo, S. (2003). Pendidikan dan Perilaku Kesehatan. Jakarta : PT. Rineka Cipta.

Pohan I. (2015). Jaminan mutu Layanan Kesehatan : Dasar-dasar Pengertian dan Penerapan.Jakarta : EGC

Perry \& Robben. 2012. Impact of Interprofessional Education On Collaboration Attitudes, Skills and Behavior Among Primary Care Professionals. Journal of Continuing Education In The Health Professions 32 (3) 196 204.

Rahayu, Sri. (2011). Pengembangan Program Patient Safety Berdasarkan Awareness dan 
Komitmen Individu. RSUD Ibnu

Sina Kabupaten Gresik

Rachmawati, Alifa Rizqia, dkk. (2017).

ANALISIS PELAKSANAAN

TUJUH LANGKAH MENUJU

KESELAMATAN PASIEN DI

RUMAH SAKIT ISLAM

SULTAN AGUNG

SEMARANG.

JURNAL

KESEHATAN MASYARAKAT

(e-Journal) Volume 5, Nomor 1

(ISSN: 2356-3346)

R.H, Simamora. (2019). Buku Ajar

Pelaksanaan Identifikasi Pasien.

Uwais Inspirasi Indonesia

R.H, Simamora. (2019). Documentation

Of Patient Identification Into The Electronic System To Improve The Quality Of Nursing Services. International Jurnal Of Sciensific \& Technology

R.H, Simamora. (2019). The Influence Of Training Handover Based SBAR Communication For Improving Patients Safety. Indian Journal Of Public Health Research \& Deveropment.

Russell J, 2001, Understanding Organizational Culture, Russell Consulting Inc $@ \quad$ Sitasi http://russell consultinginc.com/wp-
uploads/RCI_ Whitepaper__Culture.pdf..

Schein E, 2004, Organizational Culture and Leadership , 3rd Edition, 2004, Jossey-Bass.

Sorra J, Nieva V, 2007, Hospital Survey on Patient Safety Culture, AHR.

Publication No. 04-0041, September 2007.

Speroff T et al, 2010, Organisational Culture: Variation Across Hospitals and Connection to Patient Safety Climate, Qual Saf Health Care 2010;19:592-596. 